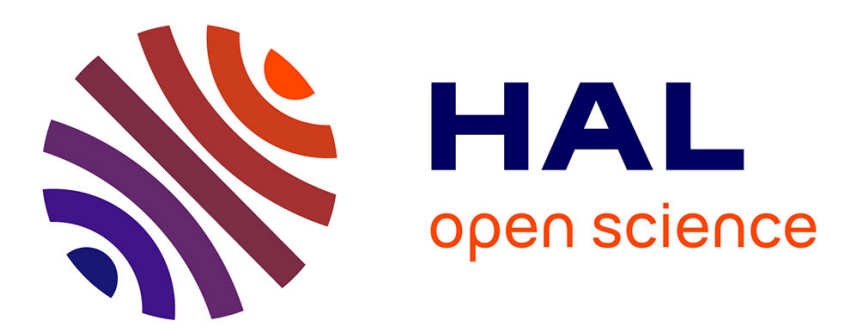

\title{
Market knowledge as a function of CEOs' personality: A fuzzy set approach
}

Barthelemy Chollet, Mickaël Géraudel, Anis Khedhaouria, Caroline Mothe

\section{To cite this version:}

Barthelemy Chollet, Mickaël Géraudel, Anis Khedhaouria, Caroline Mothe. Market knowledge as a function of CEOs' personality: A fuzzy set approach. Journal of Business Research, 2016, 69 (7), pp.2567-2573. 10.1016/j.jbusres.2015.10.137 . halshs-01496313

\section{HAL Id: halshs-01496313 \\ https://shs.hal.science/halshs-01496313}

Submitted on 27 Mar 2017

HAL is a multi-disciplinary open access archive for the deposit and dissemination of scientific research documents, whether they are published or not. The documents may come from teaching and research institutions in France or abroad, or from public or private research centers.
L'archive ouverte pluridisciplinaire HAL, est destinée au dépôt et à la diffusion de documents scientifiques de niveau recherche, publiés ou non, émanant des établissements d'enseignement et de recherche français ou étrangers, des laboratoires publics ou privés. 


\author{
Mickaël Géraudel \\ Associate Professor \\ Montpellier Business School \\ Montpellier Research in Management \\ m.geraudel@montpellier-bs.com
}

\author{
Anis Khedhaouria \\ Assistant Professor \\ Montpellier Business School \\ Montpellier Research in Management \\ a.khedhaouria@montpellier-bs.com
}

\author{
Caroline Mothe \\ Full Professor \\ University of Savoy \\ IREGE \\ caroline.mothe@,univ-savoie.fr \\ Barthelemy Chollet \\ Associate Professor \\ Grenoble Ecole de Management \\ barthelemy.chollet@grenoble-em.com
}




\section{Introduction}

The significance of entrepreneurial processes for the growth of small and mediumsized enterprises (SMEs) is evident in prior literature (Wiklund \& Shepherd, 2003, 2005). With an entrepreneurial process, SMEs apply strategy-making policies to identify and launch new opportunities. Market knowledge is critical for SMEs' entrepreneurial processes (Wiklund \& Shepherd, 2005), by helping them exploit new opportunities (Laforet, 2008; Ozgen \& Baron, 2007; Ramos-Rodriguez, Medina-Garrido, Lorenzo-Gomez, \& RuizNavarro, 2010); many SMEs rely on the ability of their chief executive officer (CEO) to mobilize such knowledge (Peters \& Brush, 1996). Miller and Friesen (1982) contend that CEOs' personality traits drive their SMEs' strategy. That is, consistent with Hambrick and Mason's (1984) upper echelons perspective, in which CEOs are responsible for setting and directing the organization's strategic orientation, CEOs' personality traits likely affect SMEs' entrepreneurial processes, through the influence of market knowledge (Rauch \& Frese, 2007).

Studies of personality traits are abundant but produce inconsistent results (Bendersky \& Parikh Shah, 2013; Ciavarella, Bucholtz, Riordan, Gatewood, \& Stokes, 2004; Collins, Hanges, \& Locke, 2004; Rauch \& Frese, 2007; Stewart \& Roth, 2001; Zhao \& Seibert, 2006). Zhao and Seibert (2006), using a meta-analytical approach to examine the relationship between the Big Five personality traits and the entrepreneurial process, indicate that openness, conscientiousness, and extraversion relate more to the entrepreneurial process do than neuroticism or agreeableness. Ciavarella et al. (2004) find that conscientiousness relates positively to the entrepreneurial process, unlike openness; extraversion, neuroticism, and agreeableness appear unrelated to the entrepreneurial process. These inconsistent results may stem from the research focus on estimating the causal effects of personality traits, with the assumption that these causes lead to the presence of an outcome (i.e., entrepreneurial processes) (Ragin \& Fiss, 2008). However, such a symmetric, causal approach cannot enrich 
understanding of relationships between configurational factors and an outcome (Fiss, 2011). This approach also is unrealistic, in that one person embodies a combination of various personality traits (Krueger, 2001, 2003).

An asymmetric, causal approach instead acknowledges that the causes leading to the presence of an outcome may different substantially from those that lead to the absence of that outcome (Ragin, 2008). This view also contrasts with a common, correlational understanding of causality, which assumes causal symmetry because correlations, by their very nature, are symmetric (Fiss, 2011; Woodside, 2013). A symmetric, causal approach also assumes that independent inputs (i.e., personal traits) are both necessary and sufficient for the presence of the outcome (i.e., the entrepreneurial process); the asymmetric, causal approach rather predicts that independent inputs are sufficient but not necessary for the outcome (Ragin, 2008). That is, high values of the independent inputs are sufficient to induce high values of the outcome, but those high independent inputs are not necessary for high outcomes, because the outcome can arise even when the values of the independent inputs are low (Woodside, 2013). Causal asymmetry thus implies the idea of equifinality, such that "a system can reach the same final state from different initial conditions and by a variety of different paths" (Katz \& Kahn, 1978, p. 30). Equifinality provides a theoretical underpinning for the persistence of various configurations, all of which can lead to a desired outcome (Fiss, 2011).

Adopting this perspective, the current study proposes a shift, from a symmetric to an asymmetric approach, to examine the effects of personality traits on the entrepreneurial process, through market knowledge. This theoretical shift can help explicate the relationships. Specifically, the comparison of the two analysis approaches (symmetric and asymmetric) reveals that studying the relationships between personality traits and market knowledge with a symmetric, causal approach provides different interpretations than does an asymmetric, causal approach. An empirical test of these arguments features a sample of 409 French CEOs from 
manufacturing SMEs and relies on fuzzy set qualitative comparative analysis (fsQCA) (Ragin, 2000, 2008). This approach reflects the notion that understanding causal relations frequently requires set-theoretic relations, rather than correlations (Fiss, 2007; Ganter \& Hecker, 2014; Ragin, 2000, 2008; Ragin \& Fiss, 2008; Woodside, 2013). As a set-based approach, fsQCA is uniquely suited to exploring complex complementarities among various factors that together influence the outcome of interest (Ganter \& Hecker, 2014; Ragin, 2000, 2008; Ragin \& Fiss, 2008; Woodside, 2013).

The results reveal several configurations of the Big Five personality traits that facilitate CEOs' market knowledge. In turn, the results help explain some inconsistent results in previous studies that take a symmetric, causal approach; the findings also suggest that no single trait is the lone key to initiating a CEO's market knowledge. No single, exclusive, causal path leads to this outcome. The significant interdependencies instead cause the contributing factors to cluster into discrete configurations that produce the outcome. This evidence also indicates causal asymmetry in the influence of several traits on CEOs' market knowledge. Thus, this study highlights the need to rethink causality to understand the relationships between the Big Five personality traits and CEOs' market knowledge.

The next section presents a comprehensive literature review of predictions about how personality traits might enhance CEOs' market knowledge, according to symmetric and asymmetric approaches. After outlining the methodology applied to collect and analyze the data, this article continues with the results and an interpretation of the findings. Next, the authors present some theoretical and practical implications, as well as the main limitations, perspectives for further research, and conclusions. 


\section{Rethinking causality to understand the relationships of the Big Five personality traits with market knowledge}

Market knowledge refers to organized, structured information about the market ( $\mathrm{Li} \&$ Calantone, 1998; Walter, Auer, \& Ritter, 2006), including customers and competitors (Bao, Sheng, \& Zhou, 2012; De Luca \& Atuahene-Gima, 2007). The acquisition and use of such market knowledge favors product innovation and enhances new product advantages (De Luca \& Atuahene-Gima, 2007; Li \& Calantone, 1998), which should improve SMEs' performance (Keh, Nguyen, \& Ng, 2007).

According to the upper echelons perspective (Hambrick \& Mason, 1984), CEOs are responsible for determining an organization's strategic orientation, with powerful influences on the entrepreneurial process in SMEs through their market knowledge (Wiklund \& Shepherd, 2005). Two main approaches might describe these links: causal symmetry between personality traits and their effects on market knowledge or causal asymmetry, such that settheoretic relations represent causality better than correlations do.

\subsection{Symmetric relationships}

In the widely used Big Five model, personality traits consist of agreeableness, conscientiousness, extraversion, neuroticism, and openness to experiences (Ciavarella et al., 2004; Leutner, Ahmetoglu, Akhtar, \& Chamorro-Premuzic, 2014; Zhao \& Seibert, 2006). Agreeableness indicates whether a person is trustworthy, altruistic, and likely to take care of others, or else is manipulative, self-centered, wary, and lacking in compassion. Conscientiousness indicates a person's degree of organization, perseverance, and motivation at work. People with low conscientiousness are disorganized and quickly discouraged. Extraversion describes the tendency to turn to the outside world. Openness to experiences measures curiosity and a willingness to search for new experiences and explore new ideas. Neuroticism or emotional instability indicates individual differences in adjustment and 
emotional stability. People with high neuroticism tend to experience negative emotions, such as anxiety, hostility, depression, self-consciousness, impulsiveness, and vulnerability. People who score low on neuroticism instead are self-confident, calm, even-tempered, and relaxed.

These personality traits, as manifested by CEOs, have important implications for the entrepreneurial process through market knowledge (Becherer \& Maurer, 1999; Ciavarella et al., 2004; Leutner et al., 2014). A predominant view classifies personality traits as "good" or "bad," with symmetric correlations with CEOs' market knowledge. For example, CEOs with personality traits that enhance their ability to access necessary knowledge about customers and competitors also exhibit a greater probability to exploit new opportunities (Ciavarella et al., 2004). Agreeable, conscious, and extraverted CEOs tend to express confidence and enthusiasm, which facilitates the development of social networks and ultimately results in knowledge gains from suppliers and customers (Bao et al., 2012), which in turn is crucial for business success (Baron \& Markman, 2000). Furthermore, conscientiousness and openness to experiences imply specific abilities to detect, treat, and use knowledge (Zhao \& Seibert, 2006). Conscientiousness appears to have a particularly powerful, positive impact on individual performance through knowledge sourcing (Judge \& Ilies, 2002). Barrick, Mount, and Judge (2001) show that conscientiousness and emotional stability often link to higher individual performance and suggest that agreeableness, openness, and extraversion are good predictors of an entrepreneurial process. Brandstätter (2011) underlines the importance of personality traits for enhancing knowledge about new business ventures, and Koe Hwee Nga and Shamuganathan (2010) note that agreeableness, openness, and conscientiousness are key determinants of the acquisition of necessary knowledge about starting a new business.

In contrast, neuroticism appears detrimental to entrepreneurial processes (Zhao \& Seibert, 2006). Neurotic CEOs express anxiety, low self-confidence and emotional volatility, which inhibits knowledge processing and individual performance (Judge \& Ilies, 2002; Zhao 
\& Seibert, 2006). If CEOs are highly self-confident, with a strong belief in their ability to control outcomes, the entrepreneurial process instead tends to succeed (Simon, Houghton, \& Aquino, 2000). Self-confidence and resilience in the face of stress therefore appear important for exploring and exploiting new opportunities (Zhao \& Seibert, 2006).

However, this predominant view of "good" and "bad" personality traits cannot depict the vast complexity of their relationships with entrepreneurial processes (Bendersky \& Parikh Shah, 2013). One person embodies a combination of personality traits that might lead to an entrepreneurial process (Krueger, 2001, 2003), suggesting the need to broaden the scope of research to encompass a more complex perspective.

\subsection{Asymmetric relationships}

An accurate understanding of these causal relationships is essential for both organization and entrepreneurship theory (Fiss, 2011; Krueger, 2003). Understanding the causal relationships between personality traits and CEOs' market knowledge can reveal the essence of entrepreneurial processes, as well as how they emerge and evolve (Krueger, 2001, 2003). Krueger (2001) suggests applying fuzzy set approaches to understand causal relationships; Woodside (2013) proposes shifting from causal symmetry to causal asymmetry. Other research acknowledges the need to take a different view on asymmetric relationships, such that "at the center of set-theoretic approaches lies the idea that relationships among different variables are often best understood in terms of set membership" (Fiss, 2007, p. 1983). This argument is both attractive and important; using causal asymmetry allows for the recognition that the personal traits that lead to CEOs' market knowledge as an outcome can differ substantially from the traits that lead to its absence (Krueger, 2003). In contrast, a correlational understanding of causality, using traditional bivariate approaches, necessarily entails causal symmetry, because correlations tend to be symmetric. For example, in modeling the inverse of "high CEO market knowledge," a correlational analysis would provide 
unchanged results, except for the sign of the coefficients. However, a causal understanding of necessary and sufficient conditions is causally asymmetric (Fiss, 2011).

Thinking about "good" and "bad" personality traits thus demands a complete reconsideration (Krueger, 2003). Even if the Big Five personality traits correlated symmetrically with CEOs' market knowledge, in a configurational approach, the causal relationships could be viewed less in terms of correlations and more in terms of sets of equally effective patterns (Krueger, 2001). The concept of causal asymmetry builds on this understanding by acknowledging that equifinality may change, depending on the outcome levels. Shifting to a causal asymmetry view thus allows for different sets of CEOs' market knowledge: One set may lead to average market knowledge; other sets could produce high or very high CEO market knowledge (Fiss, 2011; Krueger, 2001).

The current study builds on the set-theoretic methods introduced by Ragin (1987) and extended in subsequent studies (Fiss, 2007; Ganter \& Hecker, 2014; Ragin, 2000, 2008; Ragin \& Fiss, 2008; Woodside, 2013). Set-theoretic methods (e.g., fsQCA) offer unique effectiveness in terms of testing configurational theory, because in these conceptualizations, cases (observations) represent combinations of attributes, and the combinations give the cases their uniqueness (Fiss, 2011). Thus set-theoretic methods differ from conventional, variablebased approaches by avoiding the disaggregation of cases into independent, analytically separate aspects; instead, configurations represent different types of cases (Fiss, 2011; Woodside, 2013). This methodological approach can shed new light on the causal relationships between the Big Five personality traits and CEOs' market knowledge.

\section{Data and measurement}

The data for this study came from a sample of 409 CEOs of manufacturing SMEs ${ }^{1}$ located in Haute-Savoie, France. The data were collected in December 2007, using a survey

\footnotetext{
1 According to the European Commission, a SME is a firm with fewer than 250 employees (see http://ec.europa.eu/enterprise/policies/sme/facts-figures-analysis/sme-definition/index_en.htm).
} 
mailed to the CEOs of all 1,581 manufacturing SMEs listed in the databases of the HauteSavoie Chamber of Commerce and Thésame. ${ }^{2}$ The survey invitation included a cover letter, explaining that the study was supported by the Chamber of Commerce and Thésame. From the set of 427 responses, the removal of incomplete questionnaires left a sample of 409 CEOs who provided all required data. The response rate was $25.43 \%$, very satisfactory compared with the standards in other studies (Bartholomew \& Smith, 2006; Baruch \& Holtom, 2008).

To prevent self-reported biases, this study followed existing recommendations for detecting the potential for common method bias (Podsakoff, MacKenzie, Lee, \& Podsakoff, 2003; Podsakoff \& Organ, 1986). The scale anchors and format in the questionnaire varied, to avoid any method bias caused by commonalities across measures (Podsakoff et al., 2003). To address common method variance, Harman's (1976) one-factor test sought to isolate any covariance due to artifacts (Podsakoff \& Organ, 1986). A single unrotated principal component should not explain more than $50 \%$ of the variance for all indicators measured with the same method; the present results show an explained variance of $12.68 \%$, indicating no common method concerns.

Many respondents had earned graduate degrees (47.79\%), were men $(79.90 \%)$, and had long tenures with their company (more than 10 years, $57.11 \%$ ). Moreover, $44 \%$ of the firms had fewer than 10 employees, 39\% employed between 10 and 49 people, and almost $17 \%$ had between 50 and 250 employees. Firms represented the metal products $(25 \%)$ or electronics industries (24\%), followed by chemicals (18\%) and industrial machinery (13\%). ${ }^{3}$

\subsection{Outcome measure}

The main outcome variable is CEO's market knowledge, measured using a holistic measurement approach adapted to the individual level (De Luca \& Atuahene-Gima, 2007). In

\footnotetext{
${ }^{2}$ Thésame is an Arve Valley organization that provides support to local firms in the metal products, mechanical engineering, and electronics industries.

${ }^{3}$ A comparison of the final sample with the parent population revealed no statistically significant differences in firm size or sector of activity.
} 
accordance with the holistic approach, CEOs responded to a series of items. ${ }^{4}$ The factor analysis of the items revealed that five loaded above .50 on their corresponding constructs, with eigenvalues exceeding 1 (Hair, Black, Babin \& Anderson, 2010). The Cronbach's alpha value of .724 indicated the good reliability of the following items: "I have easy access to knowledge about markets," "I am aware of the evolutions in my industry," "I can anticipate major changes in my industry," "When someone needs knowledge on a market, he/she turns to me," and "I can easily identify market opportunities for my company." The resulting measure reflected the aggregate perceived level of the CEO's market knowledge.

\subsection{Independent measures}

The measures of the Big Five personality traits relied on widely used scales that exhibit strong reliability and validity (Ciavarella et al., 2004; Zhao \& Seibert, 2006). The International Personality Item Pool website ${ }^{5}$ provides translated version of the most frequently used items. This study included six items for each trait, to avoid cluttering the questionnaire and to maximize response rates. Pretests helped ensure that all items were easy to understand. The measures also achieved satisfactory reliability: agreeableness $\alpha=.812$, conscientiousness $\alpha=.776$, extraversion $\alpha=.761$, openness to experience $\alpha=.757$, and neuroticism $\alpha=.767$.

\subsection{Transforming data into sets}

The current study uses a set-theoretic approach based on fsQCA, an analytic technique that allows for assessments of how causal conditions contribute to an outcome. This approach can analyze causal processes effectively, because it reflects a configurational understanding of how causes combine to induce outcomes and can handle significant levels of causal complexity (Fiss, 2007, 2011; Ragin, 2000, 2008). Specifically, fsQCA examines causal patterns by focusing on set-subset relationships (Fiss, 2011). To explain which configurations lead to high CEO market knowledge, this method examines the members of the set of "CEO's

\footnotetext{
${ }^{4}$ The items were pretested with 5 management science researchers and 15 randomly selected CEOs.

${ }^{5}$ See http://ipip.ori.org/ipip.
} 
market knowledge traits"; identifies combinations of attributes that are associated with the outcome of interest (high CEO market knowledge), using Boolean algebra and algorithms that accept logical, complex, causal conditions; and defines a reduced set of configurations that lead to the outcome (Fiss, 2011; Ganter \& Hecker, 2014; Woodside, 2013).

To accomplish this identification of configurations empirically, QCA proceeds in three main steps (Fiss, 2011). First, with the independent and dependent variables transformed into sets, the process creates a data matrix called "a truth table" with $2^{\mathrm{k}}$ rows. ${ }^{6}$ Second, two conditions serve to reduce the number of rows: (1) the minimum number of cases required for a solution to be considered and (2) the minimum consistency ${ }^{7}$ level for the solution. In the current study, the lowest acceptable consistency for solutions was .80 , which is greater than the minimum recommended threshold of .75 (Ragin, 2008). The estimates of empirical coverage $^{8}$ then provide information about the relevance of each condition. Third, an algorithm based on Boolean algebra logically reduces the truth table rows to simplified combinations. The current study uses the truth table algorithm described by Ragin (2008), which is based on a counterfactual analysis of causal conditions and can overcome the limitations due to insufficient empirical instances (Fiss, 2011). Thus, the truth table algorithm provides parsimonious and intermediate solutions, on the basis of "easy" and "difficult" counterfactuals $^{9}$ (Ragin, 2008). A parsimonious solution includes all simplifying assumptions; an intermediate solution includes only those simplifying assumptions based on easy

\footnotetext{
${ }^{6} \mathrm{~K}$ is the number of causal conditions in the analysis (5 for this study). Each row is associated with specific combinations of attributes, and the full table lists all possible combinations. The empirical cases (observations) get sorted into the rows of the truth table on the basis of their values on these attributes, so rows may contain many, few, or no cases.

${ }^{7}$ The consistency index is analogous to a correlation coefficient and measures the degree to which membership in each solution term is a subset of the outcome (Fiss, 2011; Woodside, 2013).

${ }^{8}$ Solution coverage is analagous to the coefficient of determination $\left(\mathrm{R}^{2}\right)$ (Woodside, 2013) and measures the proportion of memberships in the outcome explained by the complete solution. Raw coverage measures the proportion of memberships in the outcome explained by each solution term assumed to be present; unique coverage measures this proportion explained solely by each solution term, "not covered by other solution terms" (Ganter \& Hecker, 2014, p. 1284).

${ }^{9}$ Easy counterfactuals refer to situations in which a redundant causal condition joins a set of causal conditions that already lead to the outcome in question. The presence or absence of the added causal condition has no effect on the outcome. Difficult counterfactuals refer to situations in which a condition can be excluded from a set of causal conditions that lead to an outcome, with the assumption that this condition is redundant; in these cases, determining whether the removed condition is redundant is more difficult (Fiss, 2011).
} 
counterfactuals. A third, complex solution includes neither easy nor difficult counterfactuals, but this solution usually is unnecessary and provides useless insights (Fiss, 2011).

\subsection{Calibration}

The fsQCA requires transforming variables into sets calibrated according to three substantively meaningful thresholds: full membership, full non-membership, and the crossover point, or "the point of maximum ambiguity (i.e., fuzziness) in the assessment of whether a case is more in or out of a set" (Ragin, 2008, p. 30). The crossover point qualitatively anchors the fuzzy set's midpoint between full membership and full nonmembership (Ragin, 2000). Following this approach produces a procedure similar to performing a z-scale transformation of original data (Ragin, 2008; Woodside, 2013). That is, the calibration of the original scale into a fuzzy set scale specified three values: the original value covering $5 \%$ of data values (full non-membership), $50 \%$ of the values (crossover point), and $95 \%$ of the values (full membership). Each variable in the original data ${ }^{10}$ then underwent calibration using the computer software subroutine in the fsQCA software program. Table 1 contains the original data values for three points for each personality trait and CEO's market knowledge.

Table 1. Summary data: market knowledge, agreeableness, conscientiousness, extraversion, openness, and neuroticism

\begin{tabular}{|c|c|c|c|c|c|c|c|}
\hline Statistics & & $\begin{array}{c}\text { Market } \\
\text { knowledge }\end{array}$ & $\begin{array}{l}\text { Agreeablenes } \\
\text { s }\end{array}$ & $\begin{array}{l}\text { Conscientiousnes } \\
\text { s }\end{array}$ & $\begin{array}{c}\text { Extraversio } \\
\mathrm{n}\end{array}$ & $\begin{array}{c}\text { Opennes } \\
\text { s }\end{array}$ & $\begin{array}{c}\text { Neuroticis } \\
\mathrm{m}\end{array}$ \\
\hline \multirow[t]{3}{*}{$\mathrm{N}$} & Valid & 409 & 409 & 409 & 409 & 409 & 409 \\
\hline & Missin & 0 & 0 & 0 & 0 & 0 & 0 \\
\hline & g & & & & & & \\
\hline Median & & 0.013 & -0.035 & -0.203 & -0.162 & -0.188 & -0.159 \\
\hline Minimum & & -3.273 & -4.959 & -3.456 & -3.805 & -4.768 & -2.672 \\
\hline $\begin{array}{l}\text { Maximu } \\
\mathrm{m}\end{array}$ & & 2.542 & 2.304 & 1.876 & 2.257 & 2.143 & 2.745 \\
\hline $\begin{array}{l}\text { Calibratio } \\
95 \%\end{array}$ & $n$ values at & 1.757 & 1.434 & 1.876 & 1.632 & 1.731 & 1.661 \\
\hline $50 \%$ & & 0.013 & -0.035 & -0.203 & -0.162 & -0.188 & -0.159 \\
\hline $5 \%$ & & -1.718 & -1.717 & -1.663 & -1.642 & -1.570 & -1.589 \\
\hline
\end{tabular}

\footnotetext{
${ }^{10}$ The original data represent factor scores, with standardized values, of the aggregated items generated using SPSS software.
} 


\section{Research findings}

Table 2 contains the results of the fsQCA of configurations that can explain CEOs' market knowledge. Black circles indicate the presence of a condition, circles with a cross point to an absence, and blank spaces indicate a "don't care" situation, in which the causal condition may be either present or absent.

Table 2. Configurational asymmetric analysis of high CEO market knowledge

\begin{tabular}{|c|c|c|c|c|c|c|c|c|}
\hline \multirow[t]{2}{*}{ Solution } & \multicolumn{5}{|c|}{ Causal Conditions } & \multirow{2}{*}{$\begin{array}{l}\text { Raw } \\
\text { Covera } \\
\text { ge }\end{array}$} & \multirow{2}{*}{$\begin{array}{l}\text { Unique } \\
\text { Covera } \\
\text { ge }\end{array}$} & \multirow{2}{*}{$\begin{array}{l}\text { Consiste } \\
\text { ncy }\end{array}$} \\
\hline & $\begin{array}{c}\text { Agreeable } \\
\text { ness }\end{array}$ & $\begin{array}{c}\text { Conscientious } \\
\text { ness }\end{array}$ & $\begin{array}{c}\text { Extravers } \\
\text { ion }\end{array}$ & $\begin{array}{l}\text { Openn } \\
\text { ess }\end{array}$ & $\begin{array}{c}\text { Neurotici } \\
\text { sm }\end{array}$ & & & \\
\hline 1 & $\bullet$ & & $\bullet$ & & $\otimes$ & 0.467 & 0.117 & 0.860 \\
\hline 2 & - & - & & - & $\otimes$ & 0.389 & 0.038 & 0.903 \\
\hline $\begin{array}{l}\text { Overall solution } \\
\text { consistency }\end{array}$ & & & & & & & & 0.852 \\
\hline $\begin{array}{l}\text { Overall solution } \\
\text { coverage }\end{array}$ & & & & & & & & 0.506 \\
\hline
\end{tabular}

Notes: These solutions are parsimonious.

The solution table shows two configurational groupings that produce high CEO market knowledge with sufficient consistency (>.75, as recommended by Ragin, 2008). These results suggest the presence of equifinality, because different configurational groupings lead to CEO market knowledge. In Solution 1, $86 \%$ of all non-neurotic CEOs who also exhibit agreeableness and extraversion achieve high market knowledge. According to the raw coverage level, each solution term present in this set (i.e., agreeableness and extraversion) explains $46.7 \%$ of a CEO's market knowledge as the outcome. Solution 2 indicates that 90.3\% of all non-neurotic CEOs who also possess agreeableness, conscientiousness, and openness exhibit high market knowledge. In this configuration, each solution term (i.e., agreeableness, conscientiousness, and openness) explains $38.9 \%$ of the outcome. 
Table 3 shows that various configurations of personality traits, and therefore various causal paths, equifinally lead to high CEO market knowledge — an important finding for which conventional, symmetric analyses cannot account sufficiently. If CEOs possess extraversion $(\beta=.176, p<.001)$ and openness $(\beta=.153, p<.01)$, they exhibit high market knowledge; the traits of agreeableness, conscientiousness, and neuroticism seem unrelated to market knowledge.

Table 3. Conventional symmetric analysis explaining high CEO market knowledge

Panel a. Analysis of variance (ANOVA) results

\begin{tabular}{llccccc}
\hline ANOVA $^{\mathrm{a}}$ & & Sum of squares & df & Mean Square & F & Sig. \\
\hline \multirow{2}{*}{1} & Regression & 40.412 & 5 & 8.082 & 9.517 & $.000^{\mathrm{b}}$ \\
& Residual & 342.260 & 403 & .849 & & \\
& Total & 382.672 & 408 & & & \\
\hline
\end{tabular}

Panel B. Coefficients

\begin{tabular}{|c|c|c|c|c|c|c|}
\hline \multicolumn{2}{|c|}{ Model } & \multicolumn{2}{|c|}{ Unstandardized Coefficients ${ }^{\mathrm{a}}$} & \multirow{2}{*}{$\begin{array}{c}\begin{array}{c}\text { Standardized } \\
\text { Coefficients }\end{array} \\
\text { Beta }(\beta)\end{array}$} & \multirow[t]{2}{*}{$\mathrm{t}$} & \multirow[t]{2}{*}{ Sig. } \\
\hline & & B & Standard Error & & & \\
\hline \multirow{6}{*}{1} & (Constant) & .009 & .046 & & .187 & .852 \\
\hline & Agreeableness & .093 & .049 & .095 & 1.891 & .059 \\
\hline & Conscientiousness & .078 & .048 & .079 & 1.638 & .102 \\
\hline & Extraversion & .172 & .047 & .176 & 3.629 & .000 \\
\hline & Openness & .150 & .048 & .153 & 3.134 & .002 \\
\hline & Neuroticism & -.052 & .047 & -.053 & -1.101 & .272 \\
\hline
\end{tabular}

${ }^{\mathrm{a}}$ Dependent variable: Market knowledge

${ }^{b}$ Predictors: (Constant), agreeableness, conscientiousness, extraversion, openness and neuroticism.

Notes: Model summary: $\mathrm{R}=.325$; adjusted R-square $=.095$; standard error $=.92156$.

These results are somewhat controversial, compared with the findings from previous, conventional, symmetric analyses. In Zhao and Seibert's (2006) study for example, openness, conscientiousness, and extraversion relate more to the entrepreneurial process than do neuroticism and agreeableness. Ciavarella et al. (2004) instead find that conscientiousness relates positively to the entrepreneurial process, in opposition with openness, and extraversion, neuroticism, and agreeableness have no relation to the process. These contradictory findings reinforce the need to use configurational groupings to reflect the complexity of causal relationships and explain the outcomes. 
A close examination of Table 2 reveals that the extraversion and openness to experience results in Table 3 become clearer with configurational groupings (Solutions 1 and 2). These configurations reveal instructive differences and commonalities; their comparison unearths further insights about which personality traits determine high CEO market knowledge. Compared with the extraversion and openness findings in Table 3, the configurations in Table 2 incorporate either the presence or the absence of other traits to reach the same outcome. That is:

- Extraversion can be associated with the absence of neuroticism and the presence of agreeableness (Solution 1).

- Openness can be associated with the absence of neuroticism and the presence of agreeableness and conscientiousness (Solution 2).

From a theoretical perspective, these configurations may explain previous inconsistent findings (Bendersky \& Parikh Shah, 2013; Ciavarella et al., 2004; Collins et al., 2004; Rauch \& Frese, 2007; Stewart \& Roth, 2001; Zhao \& Seibert, 2006). Depending on the distribution of both configurations in the sample, correlation-based approaches produce deviating results regarding their influences (Ganter \& Hecker, 2014). Only a configurational analysis does justice to both contributing factors by clarifying their association with alternative configurations related to CEOs' market knowledge. Figures 1 and 2 present plots for these two solutions from Table 2 . 


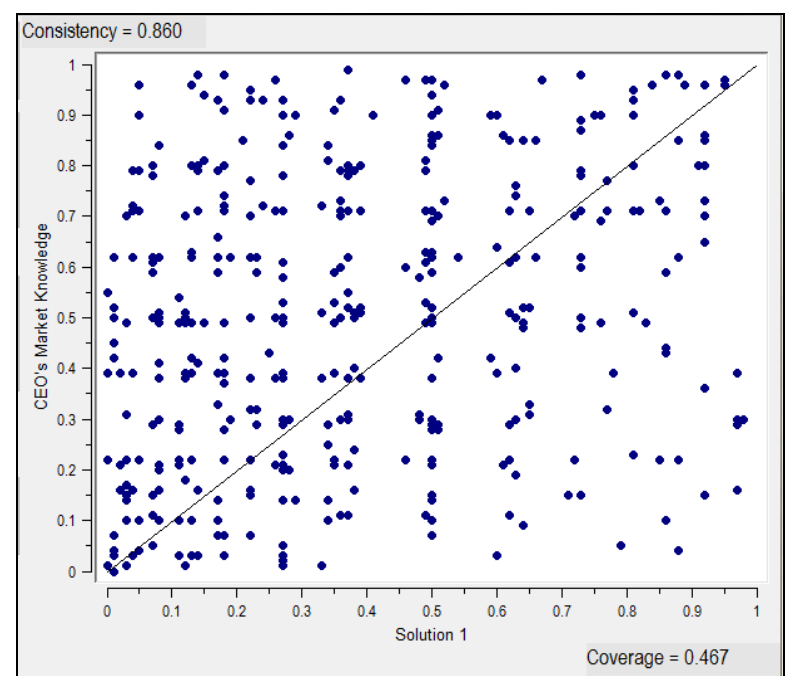

Fig. 1. Configurational groupings of Solution 1

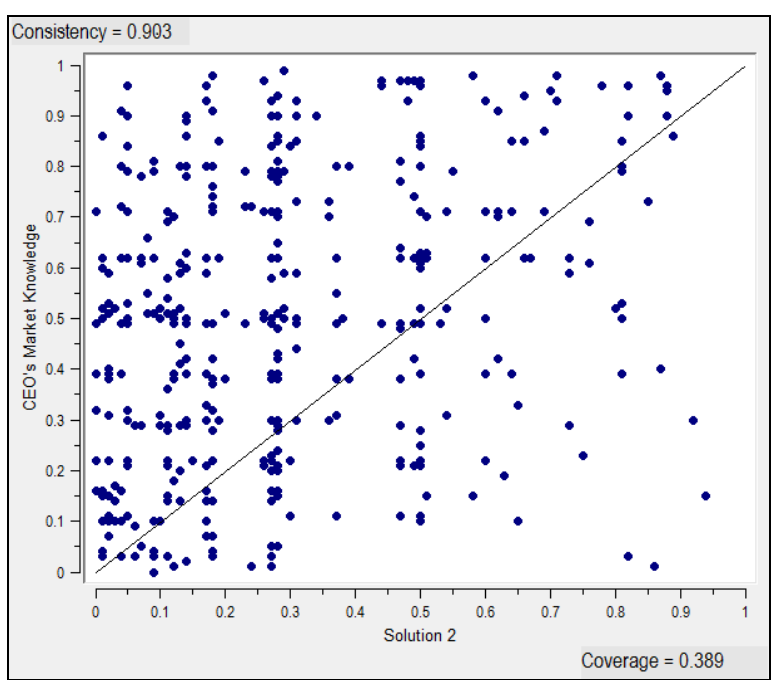

Fig. 2. Configurational groupings of Solution 2

A symmetric relationship between the causal condition ( $\mathrm{X}$ axis) and the CEO's market knowledge as an outcome ( $\mathrm{Y}$ axis) would produce clustered observations around the diagonal (Woodside, 2013). Instead, a significant number of observations locate in the top left quarter, indicating that no causal condition is necessary for high CEO market knowledge; rather, several alternative causal paths lead to this outcome. Other observations also populate the bottom right quarter, emphasizing the sufficiency of the identified solutions.

The causal asymmetry becomes even clearer from the application of fsQCA to the set of personality traits. Correlation-based analyses, by nature, suggest the same conditions determine a CEO's market knowledge, whereas fsQCA introduces different configurations that can lead to the same outcome. The empirical analysis reveals many configurations associated with the outcome, highlighting the need to accommodate causal asymmetry when studying relationships between personality traits and CEOs' market knowledge.

From a practical perspective, these results indicate that many different configurations of CEO personality traits can explain access to market knowledge. The fsQCA reveals the different configurations that lead to the same outcome. This set-based approach is useful for exploring complex complementarities of various personality traits that influence CEOs' market knowledge. 


\section{Conclusion}

The present research aims to explain some inconsistent results in previous studies of personality traits. Despite providing insights into how personality traits influence market knowledge access, prior studies remain constrained by the limitations of their symmetric, causal approach. Causal symmetry involves estimates of the causal effect of personality traits, with the assumption that causes lead to the presence of an outcome, without accounting for the complex causal interdependencies among those contributing traits. An asymmetric, causal approach instead notes that the causes leading to the presence of an outcome may differ from those that lead to the absence of the same outcome. The findings of the present study suggest two main solutions, or sets of personality traits, that produce high CEO market knowledge: (1) non-neurotic CEOs who also present agreeableness and extraversion and (2) non-neurotic CEOs who also present agreeableness, conscientiousness, and openness. The traits in each solution are configurational groupings, not "good" or "bad" separate traits. These findings thus suggest reallocating individual status within organizations or groups as a viable means to enhance the entrepreneurial process through market knowledge.

Set-theoretic methods differ from conventional, variable-based approaches, in that they do not disaggregate cases into independent, analytically separable aspects but instead treat configurations as different types of cases. The results of this study are promising and identify several equifinal configurations of personality traits that lead to CEO market knowledge. In providing evidence of complex substitutive and complementary relationships among personality traits, these findings indicate causal asymmetry in the influence of personality traits on CEOs' market knowledge. Moreover, the results demonstrate the usefulness of fsQCA for studying both personality traits and market knowledge access.

The current study also has several limitations that further research might address. For example, researchers should consider other potential antecedent factors of CEOs' market 
knowledge. Social capital can facilitate market knowledge access (Burt, 2004); sporadic interactions of weak ties also might provide access to diverse pools of knowledge sources (Granovetter, 1973), while strong ties more effectively transmit tacit, complex knowledge for experiential learning (Zhou, Wu, \& Luo, 2007).

Although the proposed measurement strategy is unlikely to suffer from common method biases, more research on this question is warranted. In particular, the data collection instrument relies on self-reported measures, and such perceptual measures can lead to biases, especially when the data collection occurs at a single point in time. To overcome this issue, additional research should collate different measures spread over time or use separate primary and secondary observations. A longitudinal study could investigate path dependencies in the development of the configurations that explain the relationships. Overall, additional applications of fsQCA to the field of entrepreneurship hold great promise for advancing knowledge about multiple issues; the present study represents an initial attempt that should spark further replications.

\section{References}

Bao, Y., Sheng, S., \& Zhou, K. (2012). Network-based market knowledge and product innovativeness. Marketing Letters, 23(1), 309-324.

Baron, R. A. \& Markman, G. D. (2000). Beyond social capital: how social skills can enhance entrepreneurs' success. Academy of Management Executive, 14(1), 106-116.

Barrick, M.R, Mount, M.K. \& Judge, T.A. (2001). Personality and performance at the beginning of the new millennium: What do we know and where do we go next? Personality and Performance, 9(1/2), 9-30.

Bartholomew, S., \& Smith, A. D. (2006). Improving survey response rates from chief executive officers in small firms: the importance of social networks. Entrepreneurship Theory and Practice, 30(1), 83-96. 
Baruch, Y., \& Holtom, B. C. (2008). Survey response rate levels and trends in organizational research. Human Relations, 61(8), 1139-1160.

Becherer, R. C., \& Maurer, J. G. (1999). The proactive personality disposition and entrepreneurial behavior among small company presidents. Journal of Small Business Management, 37(1), 28-36.

Bendersky, C., \& Parikh Shah, N. (2013). The downfall of extraverts and rise of neurotics: The dynamic process of status allocation in task groups. The Academy of Management Journal, 56(2), 387-406.

Brandstätter, H. (2011). Personality aspects of entrepreneurship: A look at five meta-analyses. Personality and Individual differences, 51(3), 222-230.

Burt, R.S. (2004). Structural holes and good ideas. American Journal of Sociology, 110(2), 349-399.

Ciavarella, M. A., Bucholtz, A. K., Riordan, C. M., Gatewood, R. D., \& Stokes, G. S. (2004). The Big Five and venture success: Is there a linkage? Journal of Business Venturing, 19(4), $465-483$.

Collins, C. J., Hanges, P., \& Locke, E. A. (2004). The relationship of need for achievement to entrepreneurship: A meta-analysis. Human Performance, 17(1), 95-117.

De Luca, L. \& Atuahene-Gima, K. (2007). Market knowledge dimensions and crossfunctional collaboration: examining the different routes to product innovation performance. Journal of Marketing, 71(1), 95-112.

Fiss, P. C. (2007). A set-theoretic approach to organizational configurations. Academy of Management Review, 32(4), 1180-1198.

Fiss, P. C. (2011). Building better causal theories: A fuzzy set approach to topologies in organization research. Academy of Management Journal, 54(2), 393-420. 
Ganter, A., Hecker, A. (2014). Configurational paths to organizational innovation: qualitative comparative analyses of antecedents and contingencies, 67(6), 1285-1292.

Granovetter, M. (1973). The strength of weak ties. American Journal of Sociology, 78(6), $1360-1380$.

Hambrick, D., \& Mason, P. (1984). Upper echelons: the organization as a reflection of its top managers. Academy of Management Review, 9(2), 193-206.

Hair, J. F., Black, W. C., Babin, B. J., \& Anderson, R. E. (2010). Multivariate data analysis. A global perspective. New Jersey, NJ: Pearson.

Harman, H. H. (1976). Modern factor analysis. Chicago, IL: University of Chicago Press.

Judge, T. A. \& Ilies, R. (2002). Relationship of personality to performance motivation: a meta-analytic review. Journal of Applied Psychology, 87(4), 797-807.

Katz, D. \& Kahn, R. L. (1978). The social psychology of organizations (2 ${ }^{\text {nd }}$ Ed.). New York: Wiley.

Keh, H. T., Nguyen, M. T. T., \& Ng, H. P. (2007). The effects of entrepreneurial orientation and marketing information on the performance of SMEs. Journal of Business Venturing 22(4), 592-611.

Koe Hwee Nga, J. \& Shamuganathan, G. (2010). The influence of personality traits and demographic factors on social entrepreneurship start-up intentions, Journal of Business Ethics, 95(2), 259-282.

Krueger, N. (2001). Opportunity emergence: A fuzzy look at the evolution of strategic vision. Western Academy of Management, Sun Valley.

Krueger, N. (2003). The cognitive psychology of entrepreneurship. Handbook of Entrepreneurship Research, International Handbook Series on Entrepreneurship, Springer $1,105-140$. 
Laforet, S. (2008). Size, strategic, and market orientation affects on innovation. Journal of Business Research, 61(7), 753-764.

Leutner, F., Ahmetoglu, G., Akhtar, R. \& Chamorro-Premuzic, T. (2014). The relationship between the entrepreneurial personality and the Big Five personality traits. Personality and Individual Differences, 63(6), 58-63.

Li, T., \& Calantone, R. (1998). The impact of market knowledge competence on new product advantage: Conceptualization and empirical examination. Journal of Marketing, 62(4), 1329.

Miller, D., \& Friesen, P. H. (1982). Innovation in conservative and entrepreneurial firms: Two models of strategic momentum. Strategic Management Journal, 3(1), 1-25.

Ozgen, E., \& Baron, R.A. (2007). Social sources of information in opportunity recognition: Effects of mentors, industry networks, and professional forums. Journal of Business Venturing, 22(2), 174-192.

Peters, M., \& Brush, C. (1996). Market information scanning activities and growth in new ventures: A comparison of service and manufacturing businesses. Journal of Business Research, 36 (1), 81-89.

Podsakoff, P. M., MacKenzie, S. B, Lee, J. Y., \& Podsakoff, N. P. (2003). Common method biases in behavioral research: A critical review of the literature and recommended remedies. Journal of Applied Psychology, 88(5), 879-903.

Podsakoff, P. M., \& Organ, D. W. (1986). Self-reports in organizational research problems and prospects. Journal of Management, 12(4), 531-544.

Ragin, C. C. (1987). The comparative method: Moving beyond qualitative and quantitative strategies. Berkley: University of California Press.

Ragin, C. C. (2000). Fuzzy set social science. Chicago: University of Chicago Press. 
Ragin, C. C. (2008). Redesigning social inquiry: Fuzzy sets and beyond. Chicago: University of Chicago Press.

Ragin, C. C. \& Fiss, P. C. (2008). Net effects analysis versus configurational analysis: An empirical demonstration. In C.C. Ragin (Ed.), Redesigning social inquiry: Fuzzy sets and beyond (pp. 190-212). Chicago: University of Chicago Press.

Ramos-Rodríguez, A., Medina-Garrido, J., Lorenzo-Gómez, J., \& Ruiz-Navarro, J. (2010). What you know or who you know? The role of intellectual and social capital in opportunity recognition, International Small Business Journal, 28(6), 566-582.

Rauch, A., \& Frese, M. (2007). Let's put the person back into entrepreneurship research: meta-analysis on the relationship between business owners' personality traits, business creation, and success. European Journal of Work and Organizational Psychology, 16(4), $353-385$.

Simon, M., Houghton, S. M., \& Aquino, K. (2000). Cognitive biases, risk perception, and venture formation: How individuals decide to start companies. Journal of Business Venturing, 15(2), 113-134.

Stewart, W. H., \& Roth, P. L. (2001). Risk propensity differences between entrepreneurs and managers: A meta-analytic review. Journal of Applied Psychology, 86(1), 145-153.

Walter, A., Auer, M., \& Ritter, T. (2006). The impact of network capabilities and entrepreneurial orientation on university spin-off performance. Journal of Business Venturing, 21(4), 541-567.

Wiklund, J., \& Shepherd, D. A. (2003). Knowledge-based resources, entrepreneurial orientation, and the performance of small and medium sized businesses. Strategic Management Journal, 24(13), 1307-1314.

Wiklund, J., \& Shepherd, D. A. (2005). Entrepreneurial orientation and small business performance: A configurational approach. Journal of Business Venturing, 20(1), 71-91. 
Woodside, A. G. (2013). Moving beyond multiple regression analysis to algorithms: Calling for adoption of a paradigm shift from symmetric to asymmetric thinking in data analysis and crafting theory. Journal of Business Research, 66(4), 463-472.

Zhao, H., \& Seibert, S. E. (2006). The Big Five personality dimensions and entrepreneurial status: A meta-analytical review. Journal of Applied Psychology, 91(2), 259-271.

Zhou L., Wu W.P., \& Luo, X. (2007). Internationalization and the performance of born-global SMEs: The mediating role of social networks. Journal of International Business Studies, 38(4), 673-690. 